\title{
SELF-EMPLOYMENT IN NATIONAL LABOUR MARKET OF KAZAKHSTAN
}

\author{
${ }^{1}$ Gottardello D., ${ }^{2}$ Kondybayeva S.K., ${ }^{3}$ Ilyashova G.K. \\ ${ }^{1}$ Doctor PhD, Universitat Rovira i Virgili, Spain, Tarragona, \\ e-mail: debora.gottardello@urv.cat \\ ${ }^{2}$ Doctor PhD, al-Farabi Kazakh National University, Kazakhstan, Almaty, \\ e-mail: $\underline{\text { saltanat.kondybaeva@,kaznu.kz }}$ \\ ${ }^{3}$ Senior lector, al-Farabi Kazakh National University, Kazakhstan, Almaty, \\ e-mail: guliya_ilyashova@mail.ru
}

\begin{abstract}
The research topic is relevant in the modern economy of Kazakhstan since the unemployed became defined as self-employed people. In addition, today, the question about their support, the legalization of their activities in order to receive taxes and social contributions to the pension and medical insurance funds arises. The aim of the study is to define criteria that allow identifying self-employment among other types of employment, determining the status of self-employment in the national economy, disclosing forms of self-employment, considering the factors and characteristics of the formation of self-employment in the modern economy and justifying the forms of state regulation of self-employment in the Republic of Kazakhstan. The article considers literature review of Foreign, Russian and Kazakh authors in defining the term "self-employment", the basic differences in analysis of the phenomenon are shown. In addition, the article gives author's definition of self-employment. The article shows trends in the development of self-employment in republic since 1991 to 2018. The basic instruments of regulating, such as laws and norms, which accepted since independent day are considered. The article shows the dynamics of the regulation improvement of the self- employment in Kazakhstan and defining the basic factors affecting their effectiveness.
\end{abstract}

Key words: labour market, self-employment, unemployment, market economy, labour policy.

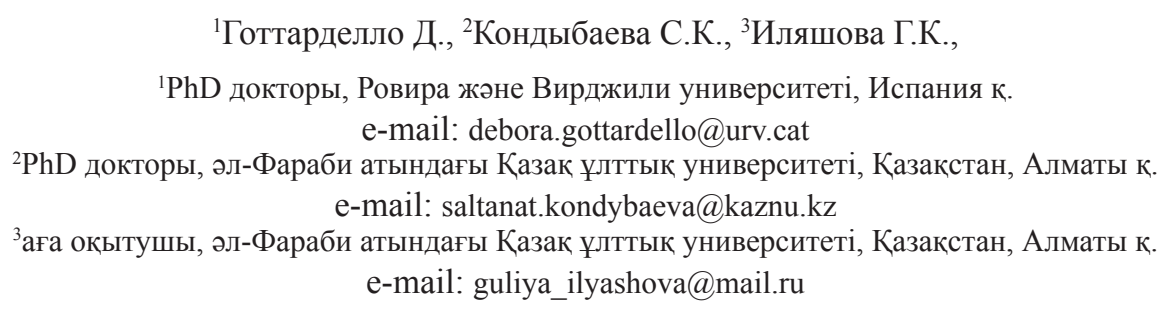

Қазақстанның ұлттық еңбек нарығындағы өзін-өзі жұмыспен қамту

Аңдатпа. Зерттеу тақырыбы Қазақстанның экономикасына өзекті болып табылады, өйткені қазіргі жағдайда жұмыссыздар өзін-өзі жұмыспен қамтыған адамдар ретінде анықталуда. Сонымен қатар, бүгінде оларды қолдау, зейнетақы мен медициналық сақтандыру қорларына салықтар мен әлеуметтік аударымдарды алу мақсатында олардың қызметін заңдастыру туралы мәселе туындады. Зерттеудің мақсаты: өзін-өзі жұмыспен қамтудың басқа түрлері арасында өзін-өзі жұмыспен қамтуды анықтауға мүмкіндік беретін критерийлерді анықтау, халық шаруашылығындағы өзін-өзі жұмыспен қамту мәртебесін айқындау, өзін-өзі құрудың факторлары мен сипаттамаларын ескере отырып, өзін-өзі жұмыспен қамту нысандарын ашу. Қазіргі экономикадағы жұмыс және Қазақстан Республикасындағы өзін-өзі жұмыспен қамтуды мемлекеттік реттеу нысандарын негіздеу. Мақалада шетелдік, ресейлік және қазақстандық авторлардың «өзін-өзі жұмыспен қамтығандар» ұғымына берілген анықтамалардың әдеби қарастырылымы келтірілген. Осы феноменді анықтауда, талдауда 
негізгі ерекшеліктері мен айырмашылықтары көрсетілген. Сонымен қоса, авторлық тұжырым да берілген. 1991 жылдан 2018 жылға дейінгі өзін-өзі жұмыспен қамтудың динамикасы талданған. Негізгі реттеу құралдары сипатталған, яғни тәуелсіздік алғаннан бері қабылданған заңдар мен нормативтер. Қазақстандағы өзін-өзі жұмыспен қамтылғандарды реттеуді жақсартудың динамикасы көрсетілген, оның тиімділігіне әсер ететін факторлар сипатталған.

Түйін сөздер: еңбек нарығы, өзін-өзі жұмыспен қамту, жұмыссыздық, нарықтық экономика, еңбек саясаты.

\author{
${ }^{1}$ Готтарделло Д., ${ }^{2}$ Кондыбаева С.К., ${ }^{3}$ Иляшова Г.К. \\ ${ }^{1} \mathrm{PhD}$, Университет Ровира и Вирджили, Испания, г. Таррагона, \\ e-mail: debora.gottardello@urv.ca \\ ${ }^{2} \mathrm{PhD}$, Казахский национальный университет им. аль-Фараби, Казахстан, г. Алматы, \\ e-mail: saltanat.kondybaeva@kaznu.kz \\ ${ }^{3}$ Старший преподаватель, Казахский национальный университет им. аль-Фараби, казахстан, г. Алматы \\ e-mail: guliya_ilyashova@mail.ru
}

\title{
Самозанятость на национальном рынке труда Казахстана
}

\begin{abstract}
Тема исследования актуальна для современной экономике Казахстана, так как на сегодня безработные стали определяться как самозанятые людьми. Кроме того, сегодня встает вопрос об их поддержке, легализации их деятельности с целью получения налогов и социальных отчислений в пенсионные и медицинские страховые фонды. Целью исследования является определение критериев, позволяющих выделить самозанятость среди других видов занятости, определить статус самозанятости в народном хозяйстве, раскрыть формы самозанятости, рассмотреть факторы и особенности формирования самозанятости. - занятость в современной экономике и обоснование форм государственного регулирования самозанятости в Республике Казахстан. В статье дается литературный обзор зарубежных, российских и казахстанских авторов определения понятия «самозанятость», показаны основные различия в подходе и анализе данного феномена. Также выдвинута авторская трактовка. Анализируется тенденция развития самозанятости в республике с 1991 года по 2018 год. Описаны основные инструменты регулирования, законы и нормативы, принятые республикой со дня получения независимости. Показана динамика по совершенствованию регулирования самозанятости в Казахстане и определены основные факторы, влияющие на эффективность их деятельности.
\end{abstract}

Ключевые слова: рынок труда, самозанятость, безработица, рыночная экономика, политика труда.

Introduction. The development and expansion of employment forms has become a new phenomenon for Kazakhstan as well as for the post-Soviet countries with a new market structure. Because the planned economy over the Soviet period had mono-employment (mono-jobs), and with the transition to a market economy people introduced with multiple jobs, and began to work in several jobs at the same time.

In the conditions of the economic restructuring, there was an urgent need to develop and substantiate the concept of transition to various forms of ownership, and, therefore, types of employment. The form of employment in any society characterizes the quality of human capital. In postindustrial countries, selfemployment has been a research problem for more than two centuries, while for Kazakhstan; it is a new issue of a market economy.

Self-employment in market conditions is an inevitable process and an inherent element of market relations. Increased business activity in the private sector and interest in generating income, responsibility for able-bodied population has particular importance in a market society. Therefore, for the economy development, there is a necessity in new initiatives to stimulate business activity and employment. This phenomenon is relevance today in many developing and developed countries.

Self-employed in the Republic of Kazakhstan is people, who provide and organize their own activities. This circumstance serves as their main source of income, they work self-sufficiently. It includes entrepreneurs, individuals engaged in individual labor contracts (ILC), members of cooperatives engaged in personal subsidiary farms (PSF). One of the main factors is dissatisfaction with the demand for jobs offered in the labor market, as it led to an increase of the self-employment among the population.

In Kazakhstan, employment has another history and logic of development: revolutionary transition from the feudal system of relations to the Soviet model, and then about 70 years of administrativecommand economic system and sharp transition to market relations led to a distorted labor market. It should be noted, that not all countries have experienced successive stages of technical progress. Many developing countries (especially former colonies) 
have passed the stage of industrial development. Such countries have political independence and remain economically dependent for more than half a century, supporting an economy with a distorted structure and a low level of economic development. The system of education, health, employment, quality of life remains on pre-industrial development level (Kulekeyev, 2016).

Literature review. The International Conference of Labor Statisticians (ICLS) considered and adopted the resolutions, where given the international definitions (standards) of various aspects of employment, unemployment and the labor market. The ICLS is guided by the UN methodology and relies on the standard system of national accounts (SNA), which has been applied in international statistics since 1953 by R. Stone, the UN Statistical Commission developed an international SNA. Its first version was adopted in 1953, the second - in 1968, the third - in 1993, the fourth - in 2008 (there are no fundamental changes, only some changes affect the level of GDP). Russia started use it in 1988, and Kazakhstan in 1993 (Mario Tovo, 2003; Dadonov, 2016).

The resolution on employment of the 13th ICLS (1982), that sets international standards into the category of employed includes wage labor and employees employed in their own enterprise (selfemployed). Partially self-employed may be entrepreneurs of any rank, employers and even employees, if they are engaged in personal subsidiary plots (Mario Tovo, 2003).

Scientists gave different definitions and approaches to the concept of self-employed. According to Schumpeter J.A., (1911) self-employment is an employment status where people work in their own business on their own account and receive an economic return for their labour in the form of wages, profits, in-kind benefits or family gain (for family workers). The self-employed may work alone or employ others. They tend to be running their own business as a sole proprietorship, independent contractor, member of a partnership, or a non-incorporated company. Hundley (2001), Benz et al. (2004) explored the differentiations between self-employment and employment and showed the main reasons of satisfaction by selfemployed. Blanchflower (2004) described the impact of self-employment on economy development. Ajayi-Obe et al (2005) mentioned the structure and evolution of self-employment in the case of Britain.

Self-employment is the production of goods and services that do not require large investments and complex forms of work organization, as mentioned by Mario Tovo (2003). Mahmud et al (2017) showed the main features of formality that workers values more.
According to Natalie Sappleton et al., individuals who opt for entrepreneurship or self-employment for personal fulfilment are considered opportunity entrepreneurs, whereas those whose choices to pursue self-employment or entrepreneurship were motivated by need are considered necessity entrepreneurs. Encouraging self-employment among the population can prolong working life in two ways. Firstly, selfemployed individuals tend to work longer over their careers than do waged workers. Secondly, policies aimed at boosting self-employment can encourage waged-and-salaried workers to migrate from employment to self-employment following formal retirement.

According to Toksanbayeva (1998), self-employment is relevant in the situation of limiting the demand for wage labor. Self-employment is a genuine alternative to wage labor from the position of alienation of labor, in which it is deprived of the entrepreneurial motivation. Under deindustrialization, self-employment may not be an informed choice, but a temporary haven, and in this sense has a negative character for the employee, that is, it becomes an alternative to not self-employed, but unemployment. The crisis growth in self-employment does not compensate for the imbalance in the labor market. Therefore, the state seeks to provide self-employed support for the formation of financially sustainable and developing forms of self-employment, as it reviewed by Volgin (1999). Cvetkova (2002) wrote in her work that, it is a situation in which wage labor can be replaced by self-employment. Despite the successes in reducing unemployment, tensions in the labor market persist, including through insufficient restructuring of the economy and self-employment (as its important component).

Most Kazakhstani scientists Meldehanova M.K. (1999), Djumambayev S.K. (2011), Dadonov V.U. (2016) have come to the determination that Selfemployment is a prerequisite for the development of entrepreneurship and the creation of own individual enterprises without employees. The problem of selfemployment is a socially-oriented process, the quantitative parameter of which is the level of pay.

Summarizing all the researches, we consider it appropriate to give a clear definition of self-employment. Self-employment is the temporary or permanent employment of people (legally and illegally) in order to provide themselves with a useful business and using public demand, which brings a certain income on the basis of economic freedom and choice in the labor market.

In a market economy, self-employment is important for population in the hired labor system, since the 
level of employment of employees strongly depends on the activities of entrepreneurs, so also outside this system. Self-employment is extremely important and promising in a market economy. Persons looking for work should not only seek the opportunity to be hired by an entrepreneur, but also try to find an opportunity for self-employment, relying on the support of small businesses by the state and local authorities.

Materials and methods. In the years of the reforms of the last century the following tendencies are characteristic of employment in the Republic of Kazakhstan: the share of people employed in the economy (without students and employed in personal subsidiary farms) decreased, the number of students of working age receiving training other than on an in-service basis had fallen. As a result, the share of the working-age population not engaged in social production increased, in turn, this meant that the unemployment rate in the economy increased. This means that the share of population engaged in personal subsidiary farming, housewives, and those who are not working is rising. The result is a decrease in the number of employees. If we consider that among the employed population, there is a large proportion of those, who work part time. Then it makes a situation, when employment does not provide a normal standard of living, especially when real wages do not satisfy the needs of the population.
This caused the transition of the population to self-sufficiency and self-employment during the period of economic reform in the Republic of Kazakhstan. Self-employment in market conditions is a mandatory objective element of market relations. Its development is due to the action of both economic and social factors. Self-employment in the Republic of Kazakhstan, one might say, existed "always", more precisely, it can be said that after the transition to market relations, it began to be vividly expressed in such activities as managing personal subsidiary farms, part-time work during vacations and evenings, tutoring, counseling, working at home, etc.

The market economy brings self-employment to a new level of commodity production, we can see it from the use of hired labor. The economic ideology of the market - the transition of every able-bodied self-reliance and self-earning. In addition, the market creates new incentives to work through the transformation of economic reality: creating an institution of private property, favorable conditions for small and medium businesses (Djumambayev, 2011).

Self-employment occupies a certain share of the labor market and a certain part of the economically active population. Today, self-employment in the Republic of Kazakhstan also has a certain level in the national economy. Figure 1 describes a dynamic of self-employment after receiving independence by RK (See fig.1):

\section{Self-employed in the Republic of Kazakhstan, as a percentage of total employment, 1991-2018}

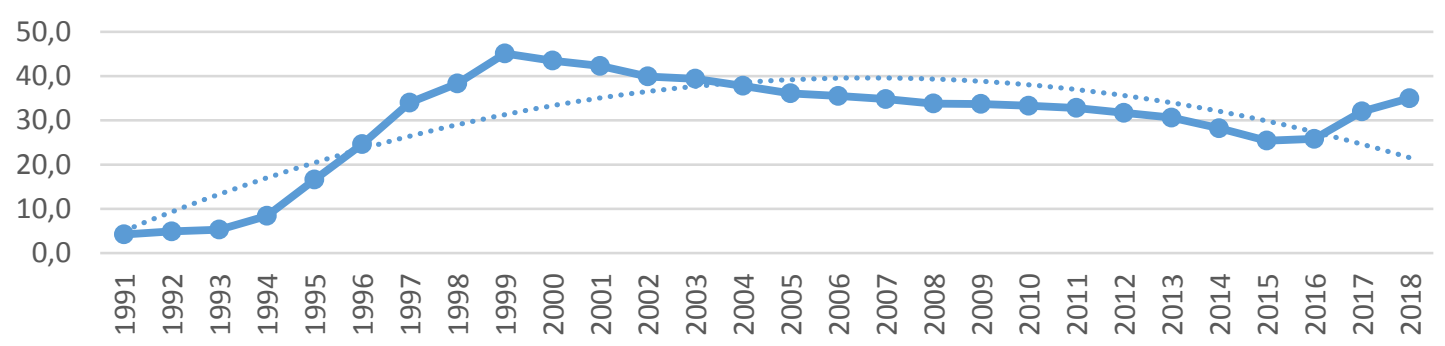

Figure 1. Self-employment in the Republic of Kazakhstan

Source: Ministry of the national economy of the Republic of Kazakhstan Committee on (statistics www.stat.gov.kz)

The number of self-employed in Kazakhstan in the second quarter of 2018 amounted to 2159.3 thousand people or $25.3 \%$ of the total number of employed population, $24 \%$ of the economically active population, $12 \%$ of the total population of
Kazakhstan. That is, self-employed represent a very significant proportion of the population of the Republic of Kazakhstan.

At the same time, the average share of selfemployed in the structure of the employed population 
for European countries is about $14 \%$. Consequently, the level of self-employment in Kazakhstan exceeds the European average by more than $11 \%$. This is due, in our opinion, to the fact that Kazakhstan has a high share of agricultural self-employment $-42.3 \%$, and a significant share of self-employed carries out its activities in the field of trade $-29.4 \%$. In developed European countries, the tendency of crowding out agricultural self-employment prevails, and selfemployment becomes the profession of individualized highly skilled professionals with large human capital.

Results and Discussion. Regulatory mechanism of Kazakhstani self-employment. Labour policy, institutions, laws, results. From the first days of independence, Kazakhstan took the path of transforming the economic and political system, focusing on the positive experience of countries with a free market economy. First, the main efforts of politicians were aimed at creating institutions of a market economy that were absent in the country. Particular attention was paid to the abolition of the old constitutional norms that guaranteed every citizen the right to work, including the right to choose a profession, and work in accordance with his or her abilities. The abolition of the former norms of the socialist Constitution, which provided full employment, and the current situation in the economy, sharply pointed out the problem of organizing a new labor market infrastructure and regulatory framework governing employment in the context of a mixed economy. Therefore, in 1990 authority focused on the preparation the law "On employment of the population" as the basic normative legal act, that regulates the basic principles and directions of state employment policy (Meldehanova, 1999).

So, Kazakhstan was the first among the republics of the former USSR that adopt this law, which began functioning on July 1, 1991; from that time the functioning of the service and the registration of the unemployed began. With the adoption of the new law "On employment of the population", the state recognized a person as the owner of its abilities for productive and creative work, while at the same time removing the responsibility for ensuring full employment of the population. On the other hand, in accordance with the norms of the new law, the state assumed the obligation to provide material and moral support to an employee who received the status of an officially registered unemployed, which included the payment of unemployment benefits, retraining of the unemployed, providing them with public works, etc.

The law "On employment of the population" was market-oriented, because the problem of employment and ensuring the balance of the labor market was proposed to be solved through market mechanisms. In 1991, in accordance with the requirements of this law, all the necessary regulatory documents were developed and adopted to create the State Employment Service (SES) and the State Fund for Assistance to Unemployed Citizens, and the State Employment Promotion Fund (SEPF) in the country. These entities assisted unemployed citizens, as a source of financing activities of the State Employment Service. Since the totality of the two institutions forms the basis for the labor exchange, the country made a decision to regulate labor market problems with the help of generally accepted mechanisms in the world.

To implement the new employment policy in accordance with the provisions of the new law "On employment of the population" and by the requirements of a multistructure economy, 370 public employment services were created in cities and regions, at the regional and republican levels. In addition, the State Employment Promotion Fund (SEPF) was established as a financial institution, whose funds were formed at the expense of compulsory contributions by organizations for $2 \%$ of the wage fund. Thus, these two institutions formed the Kazakhstan Labor Exchange with the following functions:

- the account of the unemployed and the provision of assistance in employment;

- providing advice to employers and the unemployed;

- organization of training and retraining of the unemployed;

- payment of unemployment benefits;

- development of republican and territorial employment programs;

- assistance to employers in creating additional jobs;

- analysis and forecasting of the situation in the labor market.

A labor inspection was established, as part of the state employment service. It implements the function of state control over the execution by all enterprises, institutions, organizations and other employers of all forms of ownership of current legislation on employment. The activities and the content of the state employment service were carried out with the assistance of the Employment Assistance Fund, which was subordinate to the higher territorial and central executive authorities. The bodies of the state employment service were the coordinators of the funds of the Employment Assistance Fund and were fully responsible for their targeted and lawful use. Figure 3 explains the functioning of the Labor Exchange in 1991-1998 (See fig.2): 


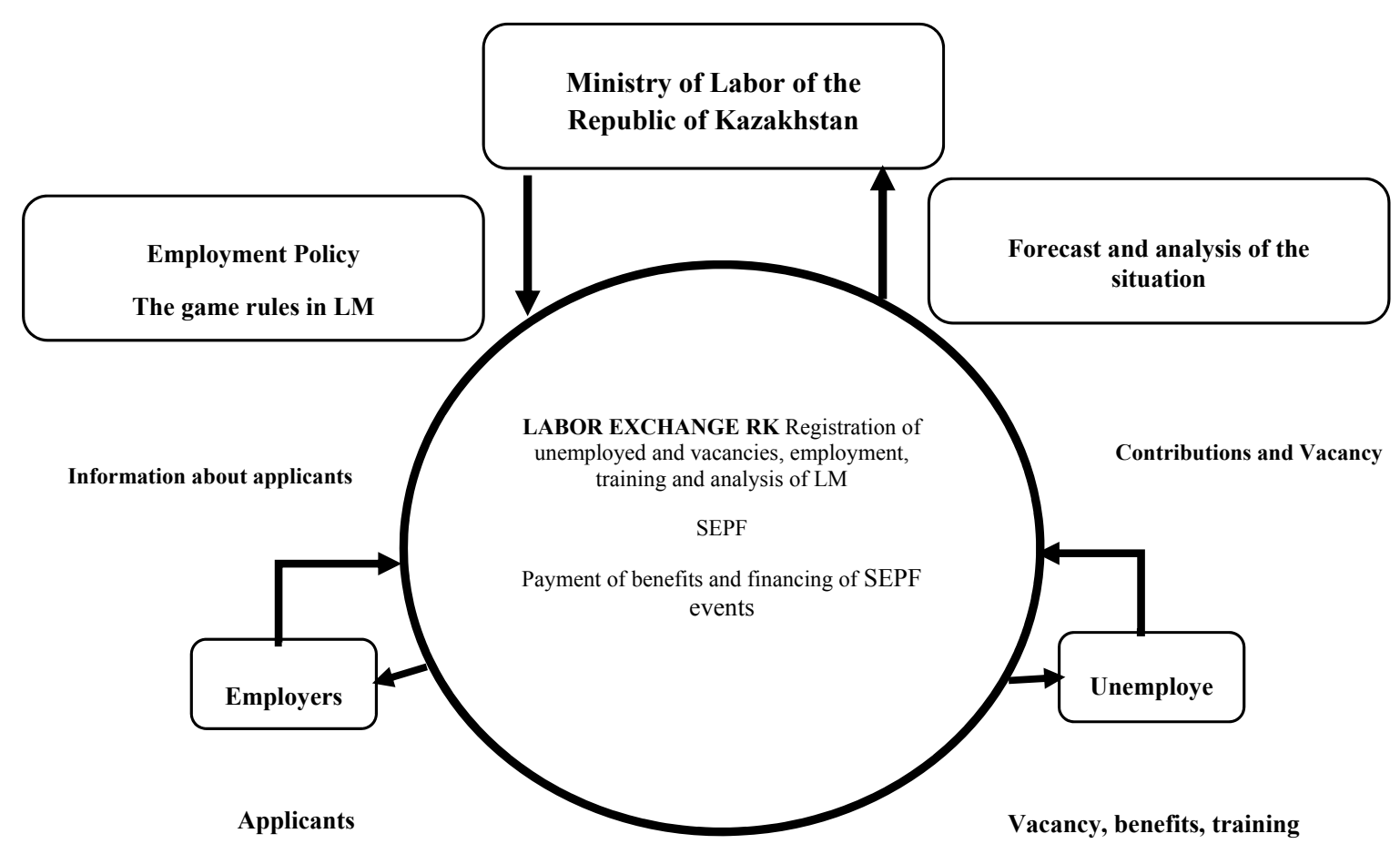

Figure 2. The scheme of the Labor Exchange functioning in the Republic of Kazakhstan from 1991 to 19982004 (Kulekeyev, 2016)

Since early 1992, the country began active work on the fundamental economy reform, the state political foundations. At the beginning of 2018, prices for basic consumer goods were released, which led to hyperinflation, deepening of the payment crisis, financial destabilization and a decline in production in all sectors of the economy. High inflation growth rates (in $1991-247 \%$, in $1992-3060 \%$, in 1993 $-2265 \%$, in $1994-1258 \%$ ) were accompanied by a depreciation of the population's savings, a decline in production led to mass unemployment. The government could not ensure macroeconomic stability because the state was in the ruble zone and did not have the tools to conduct an independent monetary policy. The sharp decline in the number of officially employed, the worsening financial situation of many economic entities led to a significant decrease in real income to the Employment Promotion Fund.

The rapid growth in the number of officially registered unemployed required from the State Employment Service and the Employment Promotion Fund a serious attitude towards solving the social problems of the unemployed. The Labor Exchange of Kazakhstan faced with a huge ball of accumulated problems in conditions of limited financial resources and high inflation. During the first years of reform (1991-1995), the country's economy faced strong difficulties, the country's aggregate demand declined by more than $30 \%$, industrial output declined by more than $50 \%$, which had a huge negative impact on the demand for labor resources. During these years, the number of employees decreased to about $30 \%$, while the number of unemployed in 1994 exceeded for the first time half a million people (Dadonov, 2016).

Therefore, during the period from 1992 to 1998, the Government made various decisions to improve the situation of the SEPF. It included financing the deficit of the Fund for the Promotion of Employment through the State Budget, the merger of the SEPF with the state budget in 1994, the reverse separation of the SEPF from the state budget in 1995 at the request of international financial institutions.

In the first years of independence, there were huge challenges. Such as liberalizing the economy, ensuring macroeconomic stability, limiting the state regulation of the enterprises economic activities, creating the basis for market infrastructure, but also in the shortest time necessary to create all the necessary institutions of an independent state (presidency institution, executive bodies, Parliament, National Bank, customs, embassies, defense, etc.). By the end of 1998, the financing costs of the State Employment Service, including the payment of unemployment benefits had reached significant figures, since the number of officially registered unemployed was 1 million people (the unemployment rate was over 
$13 \%)$. The financial possibilities of the state were extremely limited, so the priority was given to the formation of institutions of state power. For these reasons, in 1999, labor market institutions, such as the State Employment Service, the Employment Assistance Fund, which provided moral and material support to citizens seeking work, were abolished. Since that moment, unemployed citizens have stopped receiving material support from the state in the form of unemployment benefits. The functions of labor market institutes in terms of providing moral support were given to an authorized state body accountable to local executive bodies, the so-called Employment and Social Programs Coordination Service. The central authorized authorities left issues of general methodological guidance for the activities of regional employment services, as well as the collection and compilation of statistical materials. As a result, the labor market in Kazakhstan became decentralized, the coordination of employment policies was significantly weakened and a new model of the labor market began to function - figure 3:

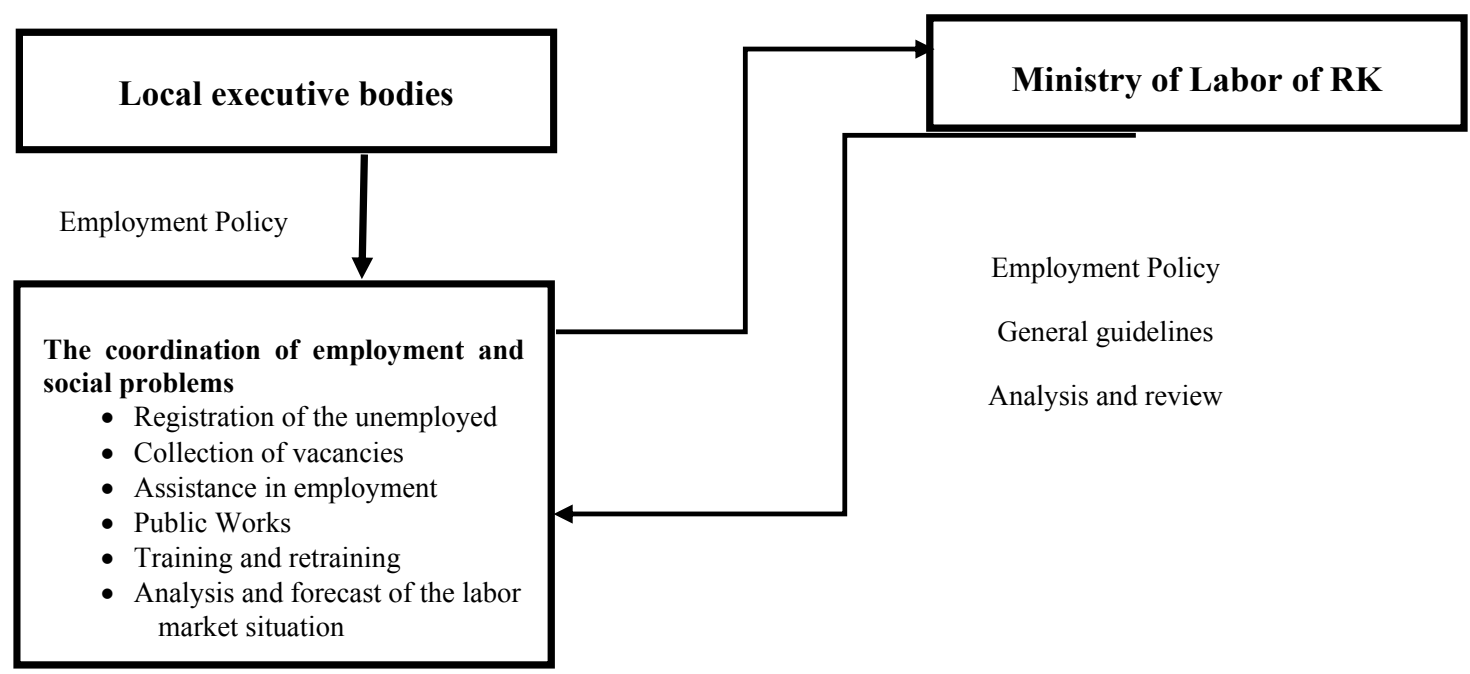

Figure 3. Scheme of interactions of labor market institutions from 1999 to 2004 (Kulekeyev, 2016).

Figure 3 shows the scheme of interactions of labor market institutions from 1999 to 2004, according to which the role of market mechanisms of labor market regulation was minimized. Since that time, job seekers have lost interest in registering with employment services and obtaining official unemployed status, because they did not promise any material benefit to them.

In the conditions of a market economy, the diversity of socio-economic processes are generating various forms of employment. Consider the modern interpretation of employment: "full, productive and freely chosen employment", used by the economists.

Full employment means a situation in a society when all persons receive paid work. In this context, on the one hand, labor is a purely voluntary affair of every person; on the other hand, if a person has expressed a desire to work, then society should provide him with this opportunity.

The productive (effective) employment must meet the two most important requirements.
First, employment must bring to the working people an income that provides decent living conditions. Second, productive employment implies the use of labor without loss with maximum efficiency. Consequently, the policy of productive employment assumes that each person's work will be economically expedient and justified from the point of providing with the maximum productivity in the existing organizational and technical conditions of production. Thus, it is opposed to formal employment, when the maintenance of full employment encourages the maintenance of surplus workers in production or an increase in the number of self-employed people.

A freely chosen employment means that the right to dispose of one's own ability to work belongs exclusively to the worker himself, i.e. he decides whether to be economically active or not, what profession to choose, in which region to live and in which workplace to work. This principle guarantees the right of every employee to choose between 
employment and unemployment, prohibiting all forms of forced employment.

The study of the Kazakhstan's labor market from the position of the international definitions of different employment forms makes it possible to notice the presence of serious structural problems. First, the relative prosperity in the labor market in Kazakhstan is due to the high proportion of the self-employed population (about $30 \%$ of the total employed population), of which only $13 \%$ are engaged in the production of goods and services for the realization. These data indicate a high proportion of unproductive and inefficient employment in the country. Consequently, a further strategy for economic growth and employment expansion should be aimed at improving quality employment.

Economists do not dispute the importance of full employment to ensure high rates of economic growth, but the facts say that not always full employment is accompanied by a reduction in poverty. It is known that the poor in many developing countries are generally not unemployed and can not break the vicious circle of poverty by hard work, because not only open and massive unemployment, but also the absence of quality employment that provides employees with a decent income level and acceptable conditions life is the cause of poverty. Thus, it is necessary to emphasize the importance of high-quality employment, which ensures the implementation of the above-mentioned principles of decent work. To implement this approach, it is necessary at the government level to intensify work on integrating employment and decent work principles into existing employment policy documents. Currently, the country has all tools and sufficient funds to turn employment into a full-fledged source of progressive development of the economy and improve the social well-being of citizens (Kulekeyev, 2016).

In this regard, the labor market of the Republic of Kazakhstan is systematically working on reforming employment centers, creating a single online platform and the full implementation of the electronic labor exchange. To this purpose, the project of law "On Amendments and Additions to Certain Legislative Acts of the Republic of Kazakhstan on Employment and Population Migration" was drafted. Since October 2017, the electronic labor exchange functioned in a pilot mode in the employment centers of Astana, Almaty, Pavlodar and Shymkent, and since January 2018 the Portal has been launched throughout Kazakhstan. At the moment the portal takes the second place in Kazakhstan in terms of attendance among the sites on the topic "Jobs and Vacancies" and 74th among all Kazakhstan sites".
Conclusion. Self-employment creates favorable conditions for individuals seeking to become entrepreneurs, provides them with opportunities to develop innovative ideas and products, which, in particular, are noted by representatives of the USA Small Business Administration. In the EU countries there are also many opportunities for choosing a specialization in the field of self-employment. In Kazakhstan, self-employed people also began to be perceived as a factor in the development of society, which responds to modern global trends. Important here is the question of how to encourage self-employed in Kazakhstan to pay taxes. At the same time, the conclusion of the self-employed of their shadow sector should become attractive both for themselves and for the state. In the conditions of the new stage communications development, In Kazakhstan, there are no effective search mechanisms between self-employed and customers of their services. The effective protection of the selfemployed in the Republic of Kazakhstan and their consolidation around the state institution is also not ensured. The purpose of the research is to develop a model for legalizing the self-employed activities and a mechanism for determining their income in the modern economy of the Republic of Kazakhstan.

With the transition to market relations, the Republic of Kazakhstan is in the process of forming and implementing an effective economic policy to ensure the country's competitiveness. It includes: diversification of the economy (in the labor market, the transition from mono-employment to multi employment, the formation of small and medium businesses); clustering (sectoral development of labor resources, development of entrepreneurship); modernization (training and retraining of personnel); innovation and industrial development (training in financial literacy of the population, training of professional personnel); industrialization in the frame of the industrial revolution (improving the health and quality of labor resources).

Nowadays, Kazakhstan is considering the ways of the revitalization of entrepreneurship. One of the option is to give for rent unused production premises to SME. It is necessary to develop proposals to reduce deductions from the wage fund. It will make conditions for businesses to create new jobs and officially pay higher salaries to employees. Legalization of wages depends on the size of these deductions.

The problem of the legalization of labor relations is other side of issue. In the conditions of an excessive number of people looking for work, the employer prefers not to form employee, but to pay a "black cash". This problem can be solved only by reducing deductions from the wage fund. 


\section{References}

Ajayi-Obe, O., Parker, S.C. (2005) The changing nature of work among the self-employed in the 1990s: Evidence from Britain. Journal of Labor Research, 26 (3), pp. 501-517. / Site: http://www.springerlink.com/content/0195-3613 doi: 10.1007/s12122-005$1017-1$

Benz, M., Frey, B.S. (2004) Being independent raises happiness at work. Swed. Econ. Pol. Rev., 11 (2), pp. 95-134.

Blanchflower, D.G. (2004) Self-employment: More May Not Be Better. National Bureau of Economic Research Working Paper No. w10286

Cvetkova S.N. (2002) Samozanyatost' kak ekonomicheskoye yavleniye, regional'naya politika i upravlyayemyy protsess [Selfemployment as an economic phenomenon, regional policy and managed process] Marketing in production, service and commerce: materials of the International conf.: part 3. South-Rostov State University of Economics and Service. Shahty: SRSUES, V. 2. P. 36-50.

Dadonov V.U. (2016) Povysheniye effektivnosti zanyatosti naseleniya v Kazakhstane: otsenka potentsiala strukturnykh izmeneniy [Increasing the effectiveness of employment in Kazakhstan: assessing the potential for structural changes] Dialogue. Politics - Law Economics. International Scientific and Analytical Journal of the Interparliamentary Assembly of the CIS Member States. St. Petersburg №2. P.109-121

Djumambayev S.K. (2011) Problemy samozanyatosti v Kazakhstane [Problems of self-employment in Kazakhstan] Weekly "Business Week" №26.

Hundley, G. (2001) Why and when are the self-employed more satisfied with their work? Industrial Relations, 40 (2), pp. 293316. / Site: http://www.blackwellpublishers.co.uk/journals/IREL/descript.htm doi: 10.1111/0019-8676.00209

Kulekeyev Zh.A. (2016) Rynok truda i zanyatost' v Kazakhstane [Labor market and employment in Kazakhstan] Kazstatinform, Almaty: 304 p.: 27

Mahmud, M., Gutierrez, I., Kumar, K., Nataraj, S. (2017) What aspects of formality do Workers value? Evidence from a choice experiment in Bangladesh.” GLM-LIC Working Paper No 37

Mario Tovo (2003) ILO. Self Employment in Italy. Journal of Man and Labour №2. P. 74-77

Meldehanova M.K. (1999) Model' effektivnogo ispol'zovaniya chelovecheskikh resursov [Population employment and economic growth: methodology, strategy and regulatory mechanism] Almaty: Institute of Economics MS\&HE RK. 295 p.

Ministry of the national economy of the Republic of Kazakhstan Committee on statistics / Site: www.stat.gov.kz - 2016

Sappleton, N., Lourenço, F. (2013) Entrepreneurship, Self-Employment and Retirement. pp. 67-89/Site: https://link.springer.com/ content/pdf/10.1057\%2F9781137398390_4.pdf

Schumpeter, J.A., [1911] (2008), The Theory of Economic Development: An Inquiry into Profits, Capital, Credit, Interest and the Business Cycle, translated from the German by Redvers Opie, New Brunswick (U.S.A) and London (U.K.): Transaction Publishers.

Toksanbayeva M.S. (1998) Samozanyatost' i yeye protivorechiya // Ekonomicheskaya nauka sovremennoy Rossii [Selfemployment and its contradictions. Economic science of modern Russia] №3. P. 32-45.

Volgin N.A. (1999) Rynok truda i dokhody naseleniya [Labor market and incomes of the population] Ed. N.A. Volgin. Tutorial. M.: Information and Publishing House "Filin": -280 p. 